\title{
E-Learning Using Wordpress on Physics Materials with The 5E Learning Cycle Strategy
}

\author{
Dewi Muliyatia ${ }^{\text {a) }}$ Herga Marizka ${ }^{\text {b) }}$, Fauzi Bakric) \\ Physics Education Department, Universitas Negeri Jakarta, Jalan Rawamangun Muka No.1, \\ Jakarta 13320, Indonesia \\ ${ }^{a)}$ dmuliyati@unj.ac.id, b)hmarizka@gmail.com, ${ }^{c}$ fauzi-bakri@unj.ac.id
}

\begin{abstract}
This article aims to publish research results in developing e-learning tools using WordPress in high school physics learning with the 5E Learning Cycle strategy. The 5E Learning Cycle Strategy consists of five stages: Engagement, Explore, Explain, Elaborate, and Evaluate. The 5E Learning Cycle Strategy refers to learner-centered learning so that online-based learning media is needed that can condition the implementation of learning following the $5 \mathrm{E}$ Learning Cycle stages. This study uses research and development that refers to the Dick and Carey model. Elearning products produce five physics topics, namely 1) Direct Current (DC) Circuit; 2) Static Electricity; 3) Magnetic Field; 4) Electromagnetic Induction; and 5) Alternating Current (AC) Circuit. It was validated by material physic experts, media experts, and learning experts, in the form of a Likert-scale questionnaire. The results of field trials using e-learning products produce $\mathrm{N}$-Gain values ranging from 0.35 to 0.40 . The study concluded that the developed e-learning could support physics learning with the Learning Cycle 5E strategy.
\end{abstract}

Keywords: e-learning, WordPress, learning cycle 5E

\section{INTRODUCTION}

The 2013 curriculum establishes a scientific approach as one of the approaches used in schools. The scientific approach is centered on students so that students can actively construct concepts, laws, or principles (Daryanto 2014). In its learning activities, the steps of the scientific approach are identical to the Learning Cycle 5E strategy (Ghaliyah 2015). Physics as one part of science, in the learning process, must be able to display scientific skills that require students to master different representations of experiments, graphs, formulas, pictures, and diagrams (Mahardika 2013). The format of representation can words, pictures, graphics, video, animation, and simulation. It has an essential role in physics learning activities. Representation of the same concept in several different formats is also called multi representation (Irwandani 2014).

Utilization of information and communication technology (ICT) enables humans to escape from space and time boundaries, exchange information to various parts of the world at any time, and can be an opportunity to be able to improve the learning process by providing learning resources that can be accessed anywhere and anytime (Suyoso 2014). Therefore, the use of ICT media can present physics learning in the form of multi representations.

One of the ICT-based and online learning media that is the current trend is e-learning. E-learning makes the process of transformation of conventional education into digital forms, both the contents and the system (Sudibjo 2013). The application of e-learning is beneficial for learning because it is flexible, allowing users to access information and learning resources without having to meet physically and not 
limited by time to carry out learning activities (Basuki 2015). E-learning can be used anywhere and anytime to support independent learning activities (Darmawan 2014). Previous research also stated that e-learning refers to the problem-based learning model in its learning activities that can help students learn independently according to the demands of 21st-century learning (Bakri, F et al. 2018).

Based on its management system, web-based e-learning can use Content Management System (CMS) and Learning Management System (LMS). LMS is an internet-based learning tool developed by the sharable content object reference model (SCORM). E-learning tools using LMS are used as electronic learning tools that help convey material and structured tasks of students with good quality (Bakri, Muliyati 2017; Yulita, Ambarwulan, \& Bakri 2018) while CMS is a system that provides convenience in managing and changing website content. The advantage of CMS is the number of templates and extensions so that it can produce a web with complete functions and features (Daru 2013). E-learning tools that have been developed using the Joomla CMS are presented in contextual and multi-representational ways that are feasible and can be used as physics learning models in high schools (Bakri, Fajriani, Muliyati 2017). So it was concluded that the development of e-learning tools uses CMS.

CMS allows web creation without having to change the format of documents into web formats such as HTML so that documents can be uploaded in word format, powerpoint, and so on. So that CMS becomes efficiently used (Ninoriya 2008). CMS types that are often used include WordPress, Joomla, and drupal. The fastest indexed by the Google search engine is Wordpress (Andi 2010). Wordpress is a service site that uses a Wordpress engine; by registering on the wordpress.com site users do not need to do any problematic installation or configuration. Creating an e-learning portal using WordPress easy enough to save time; there are more than 27 thousand plugins available in WordPress (Messenlehner 2014). With the availability of plugins on the WordPress site, WordPress can display the steps of the learning cycle model.

\section{METHODS}

This study aims to produce e-learning tools using WordPress in high school physics learning with a $5 \mathrm{E}$ learning cycle strategy. The study was conducted in a digital media laboratory majoring in physics, Jakarta State University. This study uses a development research method that refers to the Dick and Carey model. The product produced in this study is e-learning that can support independent learning activities so that understanding of learning material is meaningful. The development research procedure with the Dick \& Carey model only follows the first step up to step nine because the tenth step is outside the learning system (Meredith 2003). The resulting e-learning tool can also facilitate students in understanding physics material. The products were validated by material physic experts, media experts, and learning experts, in the form of a Likert-scale questionnaire. The results of field trials using e-learning products produce $\mathrm{N}-$ Gain values based on pre-test and post-test.

\section{RESULTS AND DISCUSSIONS}

The e-learning tool uses WordPress for high school physics material consisting of several components as follows.

\section{Product Description}

\section{Homepage}

Home is the starting page on e-learning using WordPress. The homepage displays the Jakarta State University logo with the title e-learning, navigator search, menus in the header section, namely home, instructions, material, discussion forums, registers, logins, and about us. There are photos as a slider, subject matter, and facilities, as well as several widgets at the bottom of the homepage display. 


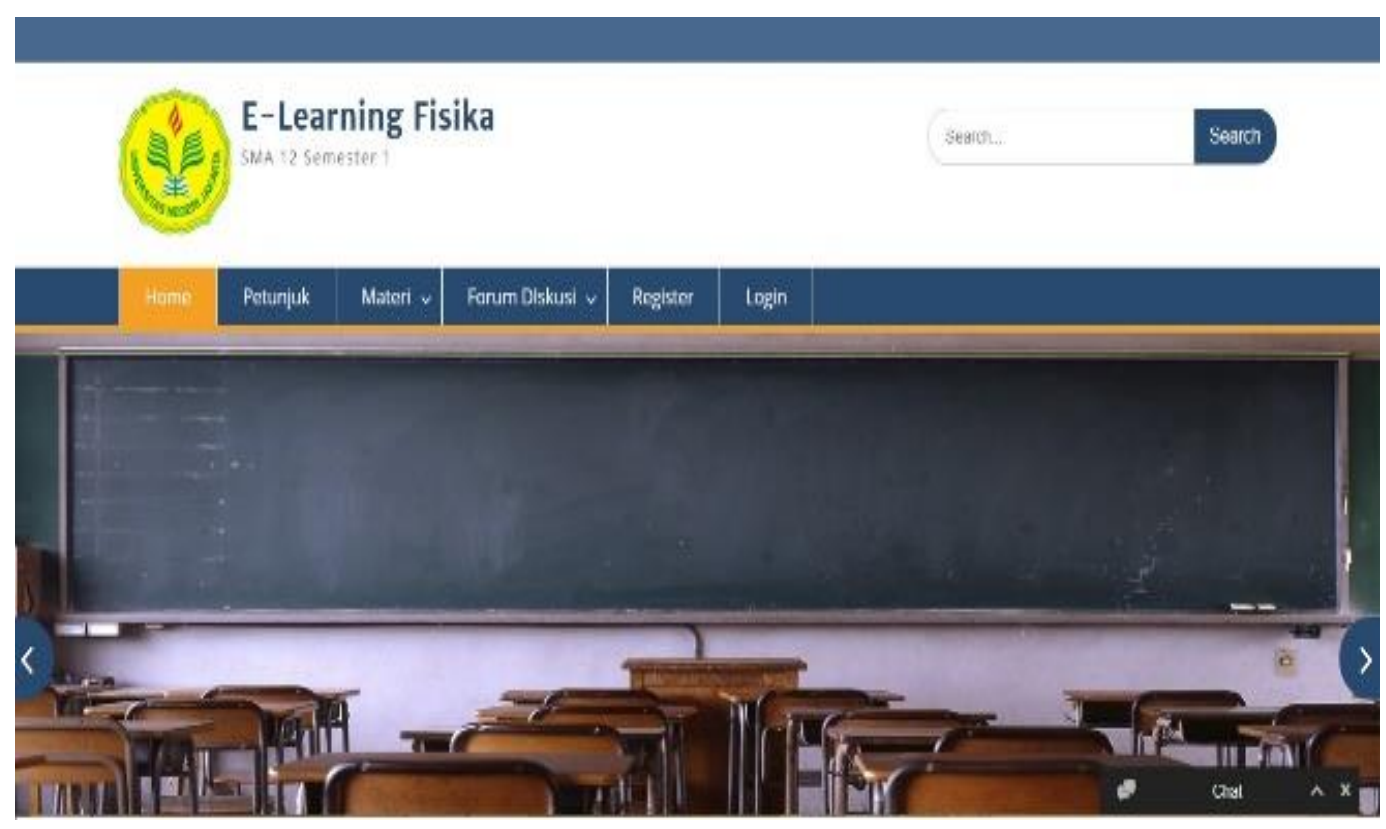

FIGURE 1. Display homepage in e-learning

\section{\begin{tabular}{l|l|l|l|l|l} 
Home & Pexunjuk & Materi $~$ & Forum Dlskusi $~$ & Register & Login \\
\hline
\end{tabular}}

Register

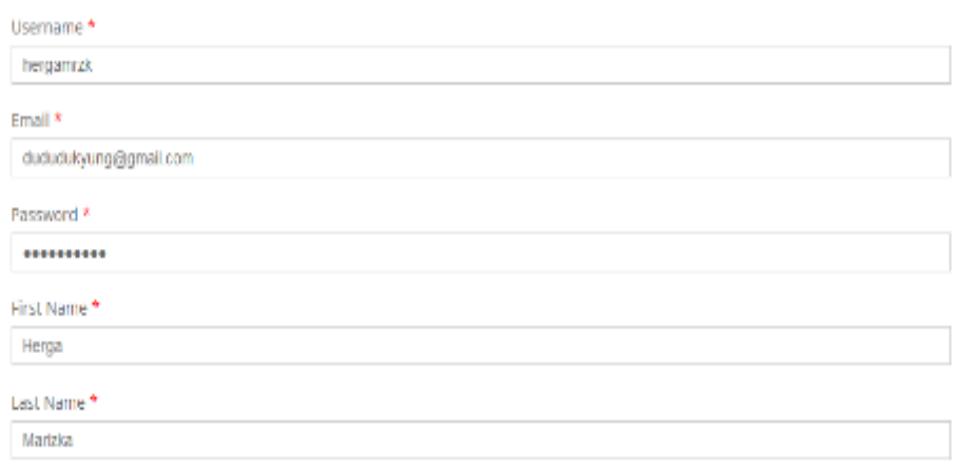

Reaster

$\cdot$

FIGURE 2. Display register page 

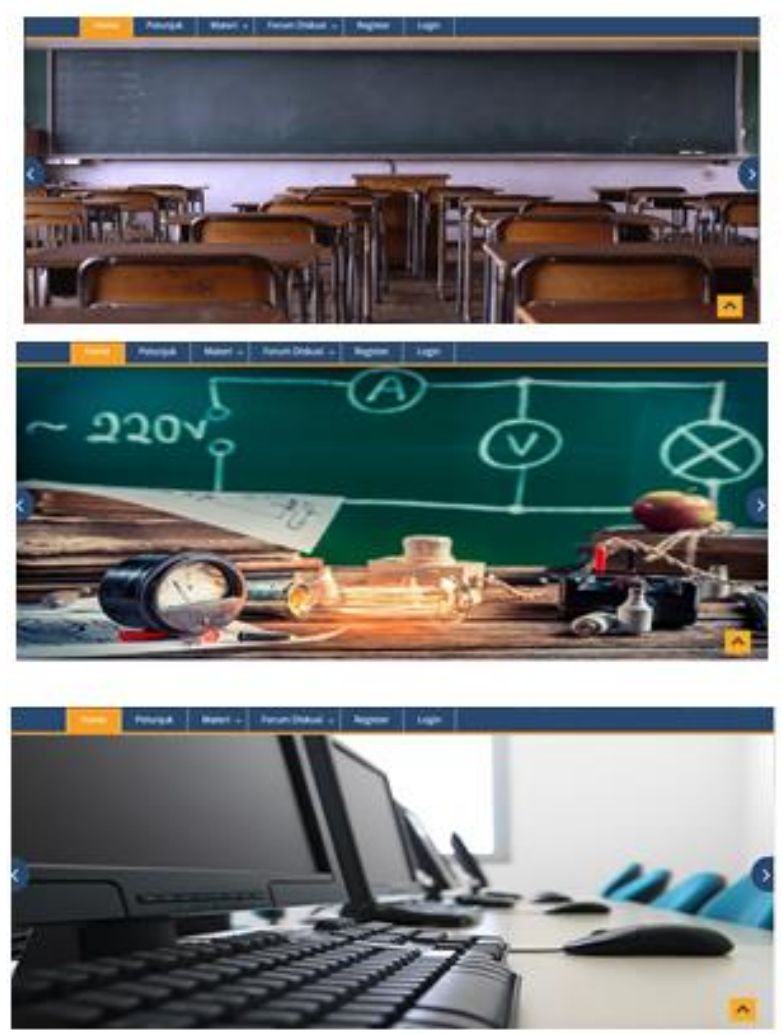

FIGURE 3. Display slider on homepage

Materi Pelajaran
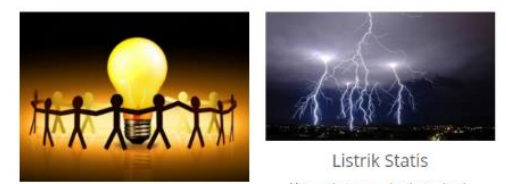

Rangkaian Arus Searah

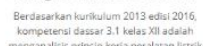
Listrik Statis

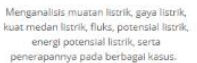

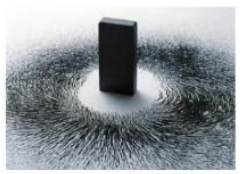

Medan Magnet Rend more.

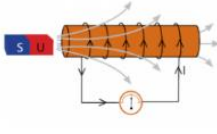

Induksi Elektromagnetik
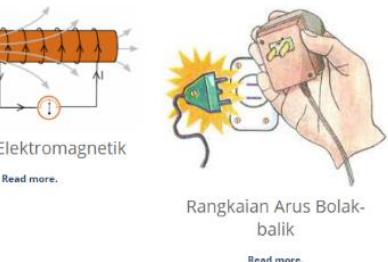

Fasilitas
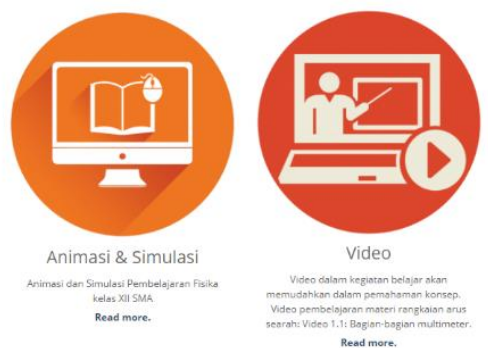

FIGURE 4. Display homepage after scrolling. 


\section{Content}

In the material menu, physics material is displayed that can be accessed after the user has logged into e-learning.

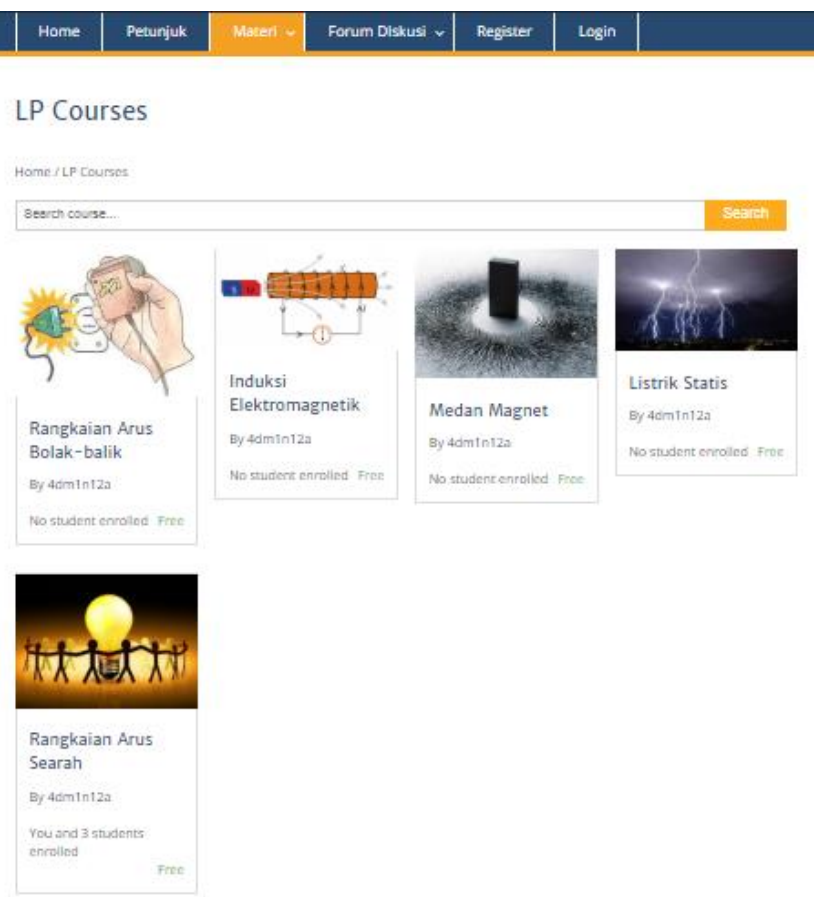

FIGURE 5. Display material in e-learning Rangkaian Arus Searah

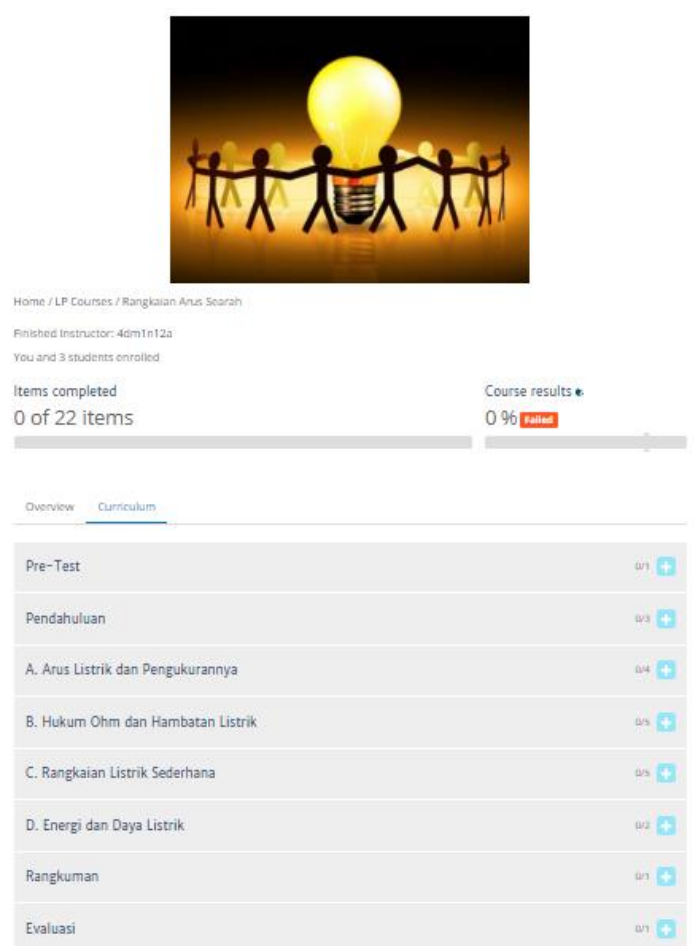

FIGURE 6. Display sub material 


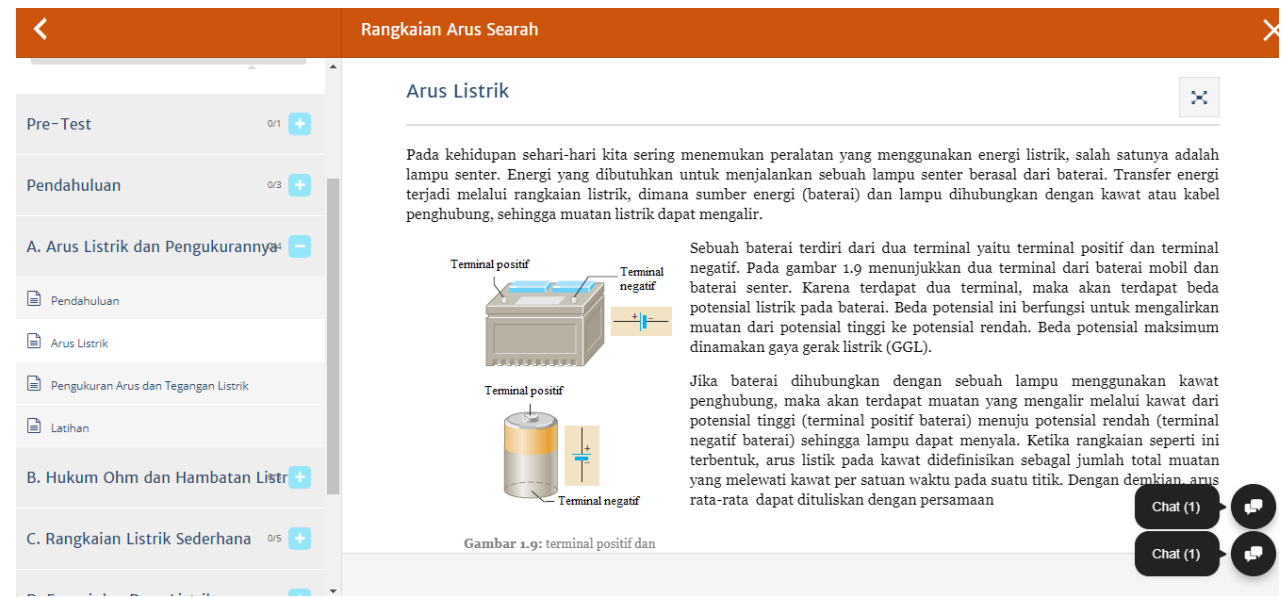

FIGURE 7. Display explanation material

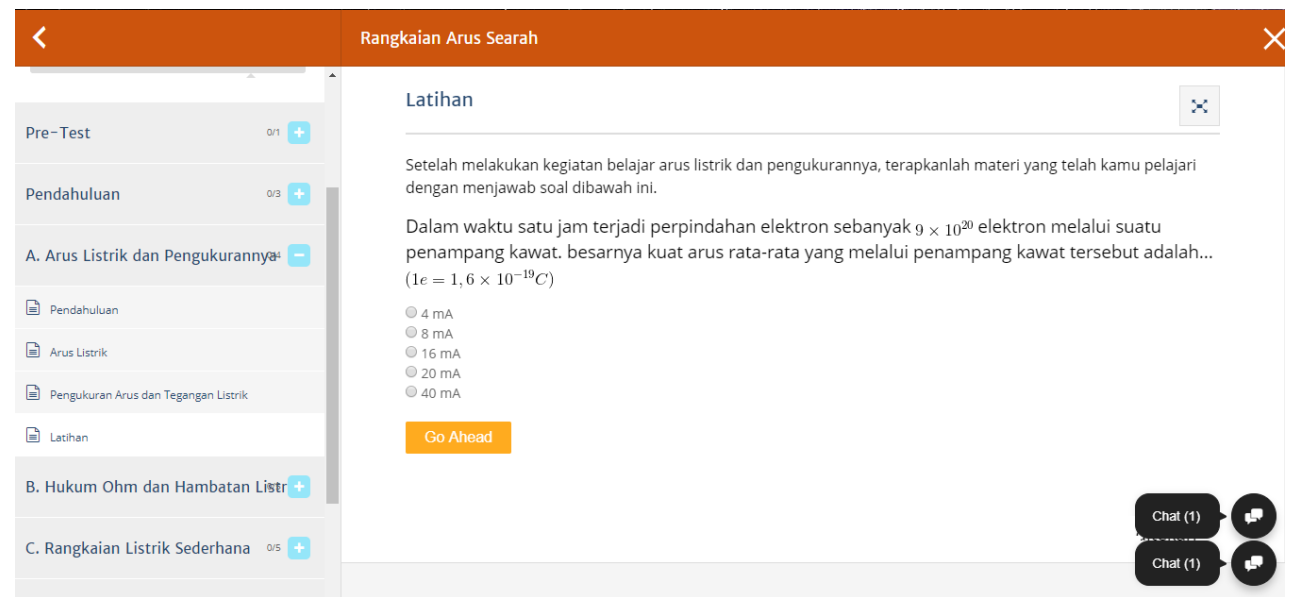

FIGURE 8. Display practice questions

Submission of material in the e-learning tool uses a 5E learning cycle strategy with five stages, namely engaging, exploring, explaining, elaborating, and evaluating. The first stage is exploring, students are given questions about what they already know about the topic to be studied. The engage phase aims to find out the level of understanding of students as initial knowledge they have. This stage can be presented in the form of demonstrations, questions, graphics, or events, or phenomena.

Second, the explore phase, students are given direct experience before being given an explanation of subject matter that can be done by observing, questioning, investigating, testing predictions, hypothesizing, and communicating with other colleagues. In e-learning, at this stage, students are given instructions to form groups and conduct discussions in discussion forums discussing the problems raised, then each student writes the answers to the discussion in the column provided.

The third stage is explained; at this stage the process of clarifying misunderstanding takes place, which can be in the form of definitions, notes, videos, and visual aids to help students' understanding. Students are presented with subject matter supported by pictures, animations, and videos related to the material discussed.

Next to the elaborate stage, at this stage students apply a conceptual understanding that can be done with additional investigations, developing products, or sharing information or ideas. In e-learning, this stage is presented with exercises with multiple choice answers, so students must choose one correct answer. Finally, the evaluate stage, this stage is done through a summative test, which can be in the form of quizzes, exams, or assignments (Duran 2004). 


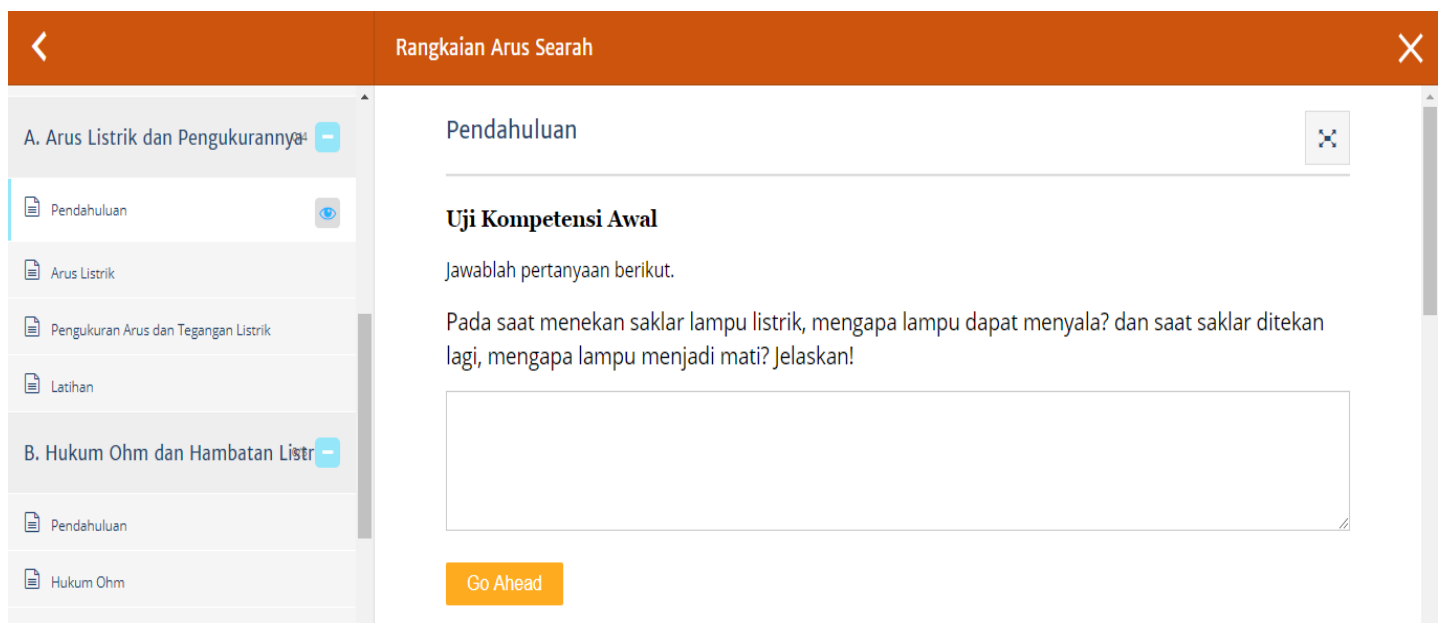

FIGURE 9. Display material according to the learning cycle stage 5E: The engage phase

\begin{tabular}{|c|c|}
\hline$<$ & Rangkaian Arus Searah \\
\hline A. Arus Listrik dan Pengukurannya - & Kegiatan 1.1 \\
\hline -1) Pendathuluan & $\begin{array}{l}\text { 1. Buatlah kelompok kecil yang terdiri atas } 4 \text { orang/kelompok. } \\
\text { 2. Masing-masing kelompok dapat masuk ke dalam ruang diskusi untuk mendiskusikan permasalahan terkait konsep yang dipelajari. } \\
\text { untuk dapat masuk kedalam ruang diskusi, klik di sini. }\end{array}$ \\
\hline Dit Arus Listrik & 3. Diskusilah secara berkelompok, kemudian jawablah pertanyaan dibawah ini. \\
\hline D. Pengukran Arus dan Tegangan Listrik & \\
\hline 国 Lathan & Misalkan kita memiliki sebatang kawat konduktor AB. \\
\hline B. Hukum Ohm dan Hambatan Listr- & $\underset{A}{A_{B}}$ \\
\hline -1) Pendahuluan & $\begin{array}{l}\text { Jika ujung A merupakan kutub positif dan ujung B merupakan kutub negatif, jelaskan bagaimana gerakan elektron } \\
\text { dan gerakan arus listrik pada kawat konduktor AB. }\end{array}$ \\
\hline E) Hukumohm & \\
\hline I] Hambaran Listrik Kawat Penghantar & \\
\hline 国 Pengaruh Temperatur Terhadap Hambatan Kawat & \\
\hline I Latihan & Go Ahead \\
\hline C. Rangkaian Listrik Sederhana ois - & $\rightarrow$ \\
\hline
\end{tabular}

FIGURE 10. Display material according to the learning cycle stage 5E: The explore phase

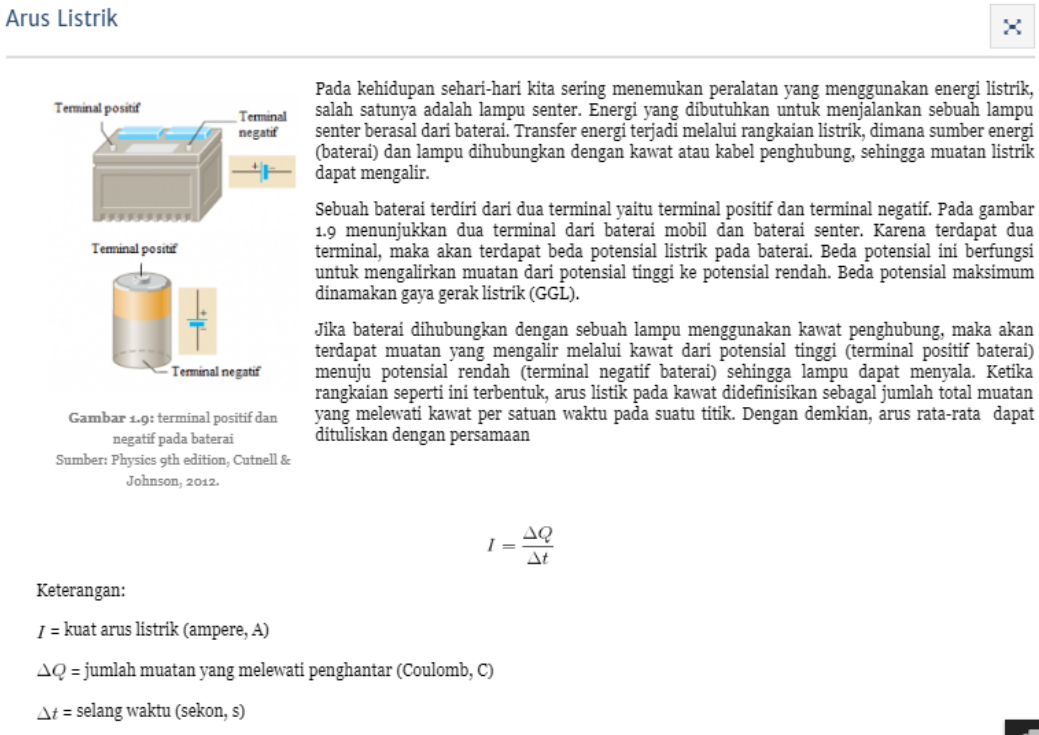
negatif pada baterai Sumber: Physics gth edition, Cutnell \&. Johnson, 2012.

Pada kehidupan sehari-hari kita sering menemukan peralatan yang menggunakan energi listrik, salah satunya adalah lamp senter. Energi yang dibrtuhkan yntak menjankan sebuah lamp (baterai) dan lampu dihubungkan dengan kawat atau kabel penghubung, sehinge mutan listrik Sebuah baterai terdiri dari dua terminal yaitu terminal positif dan terminal negatif. Pada gambar 1.9 menunjukkan dua terminal dari baterai mobil dan baterai senter. Karena terdapat dua terminal, maka akan terdapat beda potensial listrik pada baterai. Beda potensial ini berfungsi untuk mengalirkan muatan dari potensial tinggi ke potensial rendah. Beda potensial maksimun

Jika baterai dihubungkan dengan sebuah lampu menggunakan kawat penghubung, maka akan terdapat muatan yang mengalir melalui kawat dari potensial tinggi (terminal positif baterai) menuju potensial rendah (terminal negatif baterai) sehingga lampu dapat menyala. Ketika rangkaian seperti ini terbentuk, arus listik pada kawat didefinisikan sebagal jumlah total muatan yang melewati kawat per satuan waktu pada suatu titik. Dengan demkian, arus rata-rata dapat dituliskan dengan persamaan$$
I=\frac{\Delta Q}{\Delta t}
$$

Keterangan:

$I=$ kuat arus listrik (ampere, $\mathrm{A}$ )

$\Delta Q=$ jumlah muatan yang melewati penghantar (Coulomb, C)

$\Delta t=$ selang waktu (sekon, s)

FIGURE 11. Display material according to the learning cycle stage 5E: The explain phase 


\section{Rangkaian Arus Searah}

Latihan

Setelah melakukan kegiatan belajar arus listrik dan pengukurannya, terapkanlah materi yang telah kamu pelajari dengan menjawab soal dibawah ini.

Dalam seutas kawat, mengalir muatan listrik sebesar $6 \mu \mathrm{C}$ setiap detik. Kuat arus listrik rata-rata yang melalui penampang kawat adalah .....

$$
\begin{aligned}
& 6 \mu C \\
& 10 \mu C \\
& 60 \mu C \\
& 100 \mu C \\
& 600 \mu C
\end{aligned}
$$

FIGURE 12. Display material according to the learning cycle stage 5E: The elborate stage

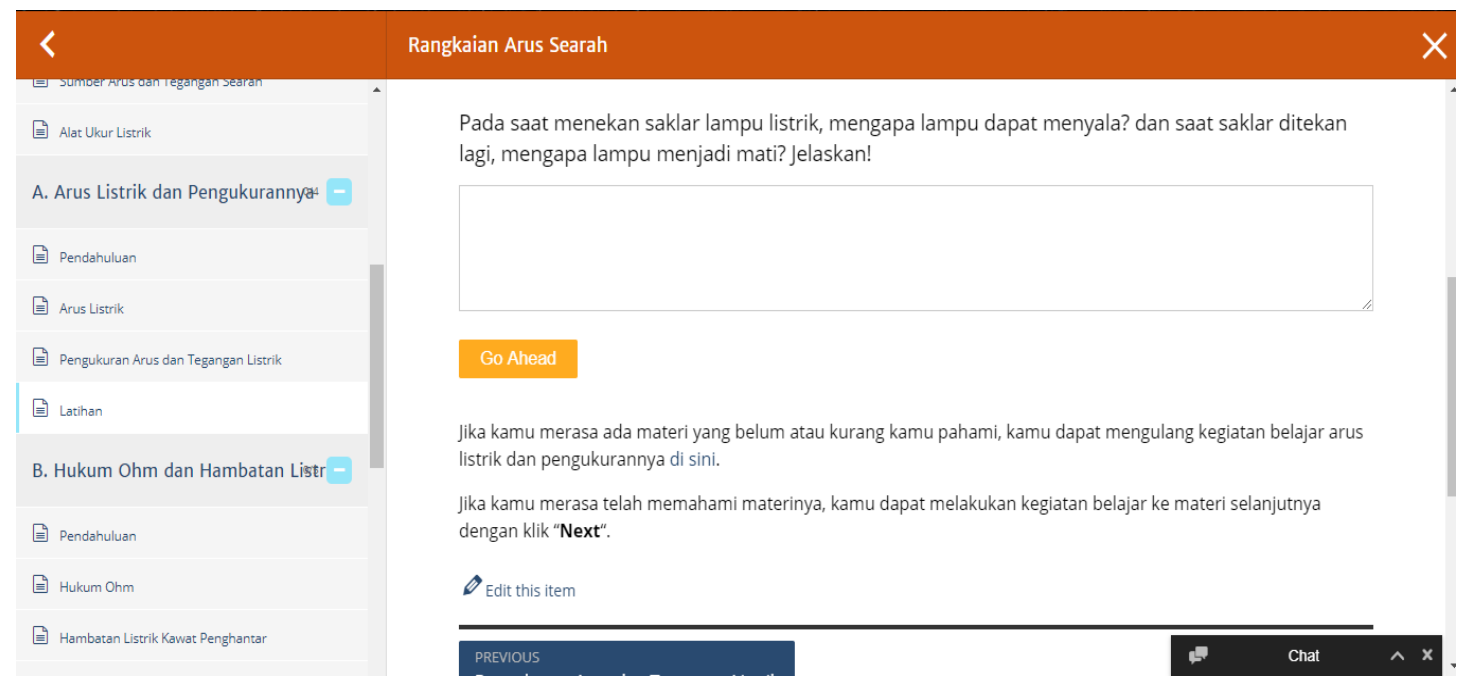

FIGURE 13. Display material according to the learning cycle stage 5E: Evaluate stage

\section{Evaluate}

In the evaluation section, some questions must be resolved by the user.

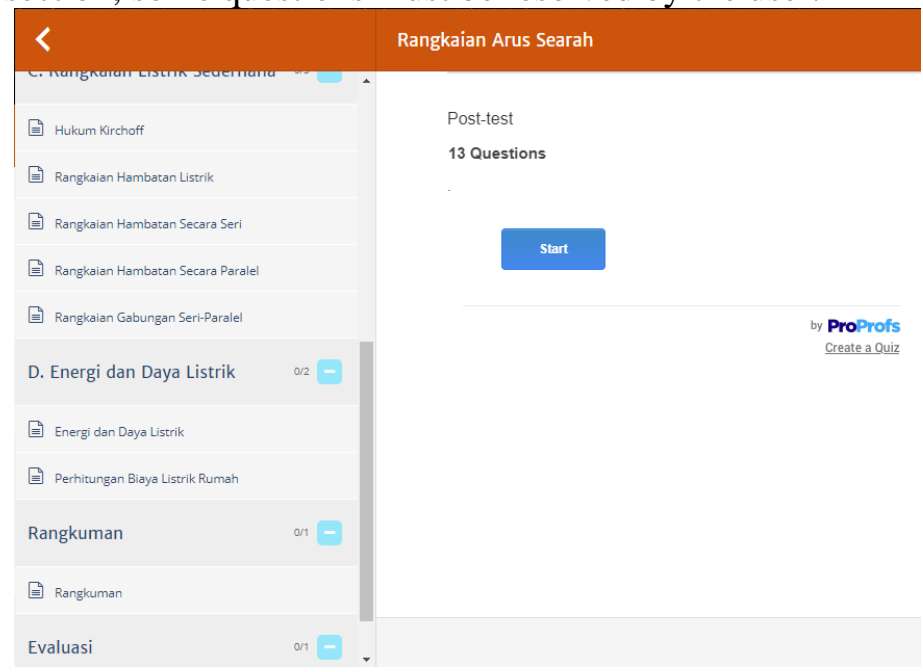

FIGURE 14. Display evaluation in e-learning 


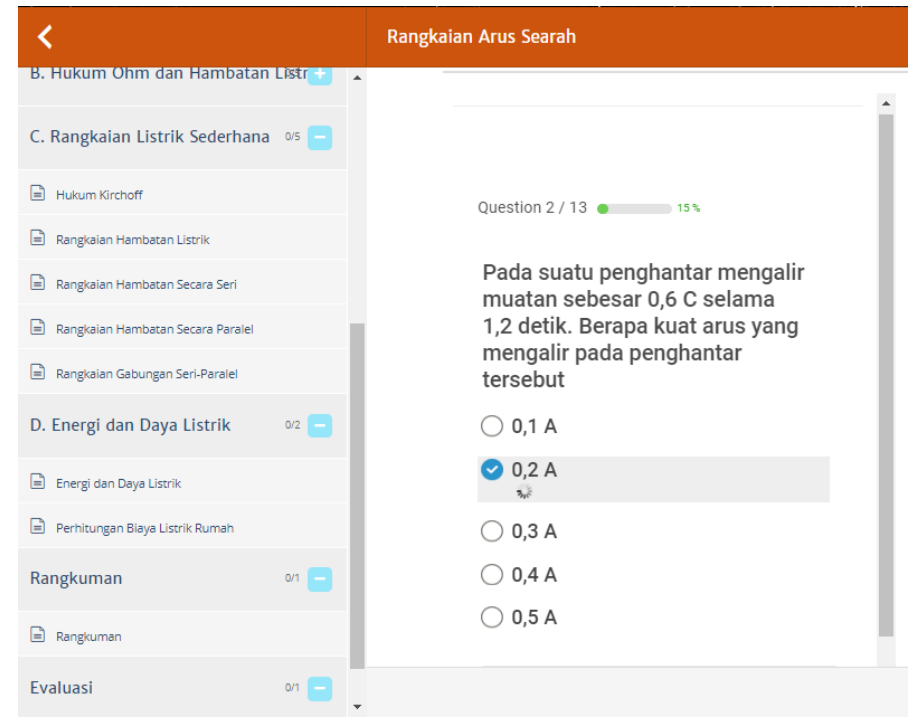

FIGURE 15. Display evaluation questions (multiple choice)

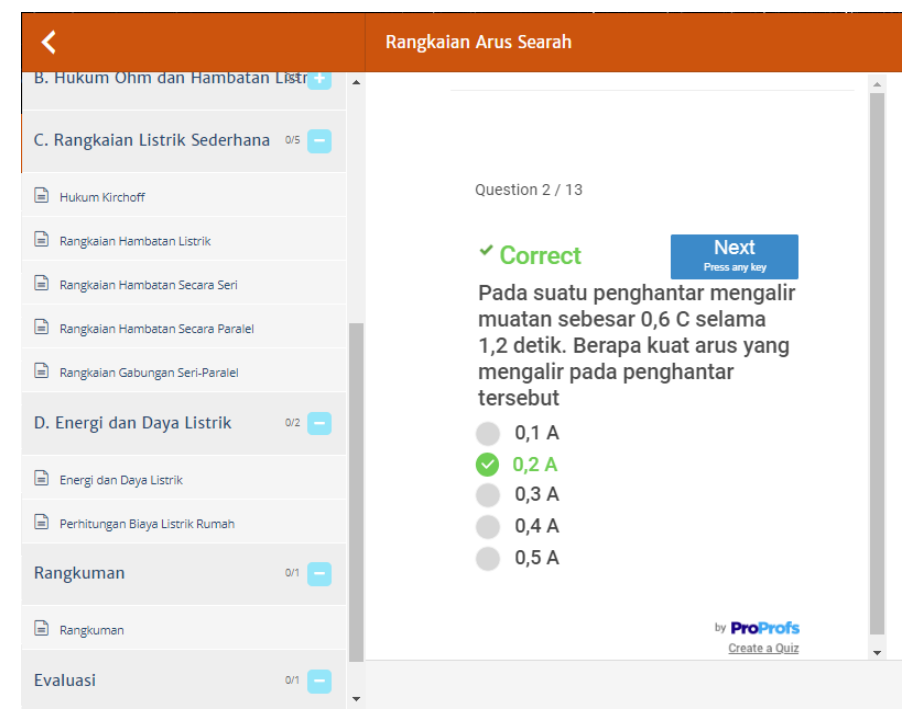

FIGURE 16. Display evaluation questions if the user answers correctly

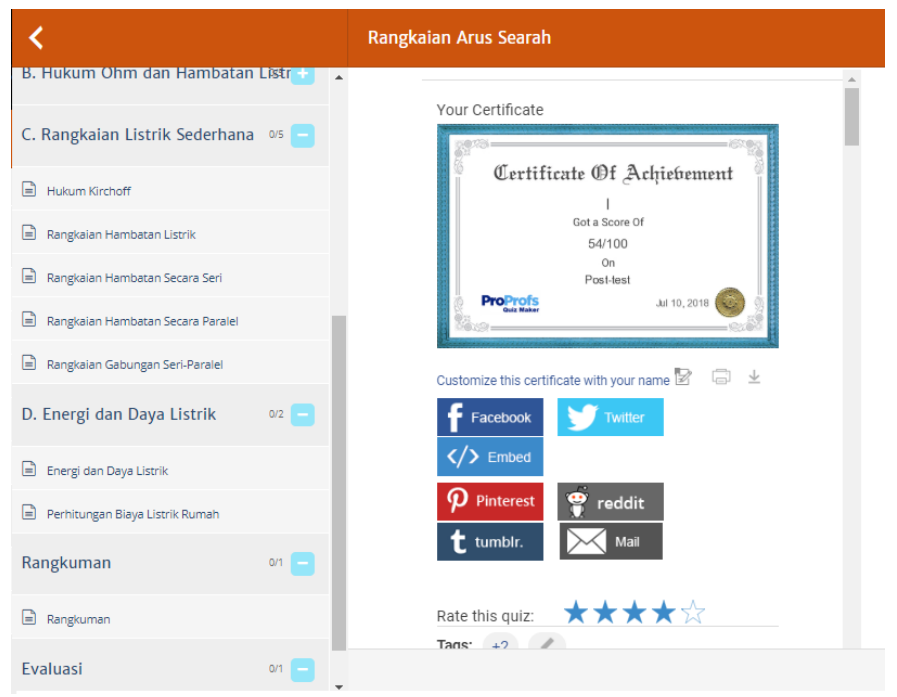

FIGURE 17. Display after the user has finished answering all evaluation questions. 


\section{Formative Evaluation}

The results of the formative evaluation of the e-learning tools produced obtained that the device still needs to be developed to be used as a medium of independent learning in physics learning. Formative evaluation is carried out in the form of due diligence. There are three feasibility tests conducted in the formative evaluation, namely the media feasibility test, learning, and material.

Feasibility tests by media experts got $92.43 \%$ results with a very proper interpretation that can detail aspects of TABLE 1 . It shows that the e-learning media developed is feasible to be used as learning media.

TABLE 1. The results of the feasibility test by media experts

\begin{tabular}{ccc}
\hline \multicolumn{1}{c}{ Aspect } & Percentage & Interpretation \\
\hline E-Learning system & $95 \%$ & Very good \\
E-Learning content & $92.3 \%$ & Very good \\
E-Learning infrastructure & $90 \%$ & Very good \\
\hline Average & $92.43 \%$ & Very good \\
\hline
\end{tabular}

The feasibility study conducted aims to determine the feasibility of implementing learning steps in e-learning tools. E-Learning tools developed to get the results of the feasibility study of $85 \%$ with very proper interpretation. It shows that learning in e-learning is appropriate to be used as a learning medium for high school students.

TABLE 2. The results of the feasibility test by learning experts

\begin{tabular}{ccc}
\hline Aspect & Percentage & Interpretation \\
\hline Presentation of learning materials & $80 \%$ & Good \\
Learning activities & $90 \%$ & Very good \\
Learning Cycle 5E stages & $85 \%$ & Very good \\
\hline Average & $85 \%$ & Very good \\
\hline
\end{tabular}

A material feasibility test is carried out for every one chapter in e-learning with the same aspects. The aspects assessed are the scope of the material, the compatibility of the components with physical material, and the language of use. There are five chapters in e-learning so that the assessment of the results of the material feasibility test is different. The results of the due diligence test by material experts can be seen in FIGURE 18 below.

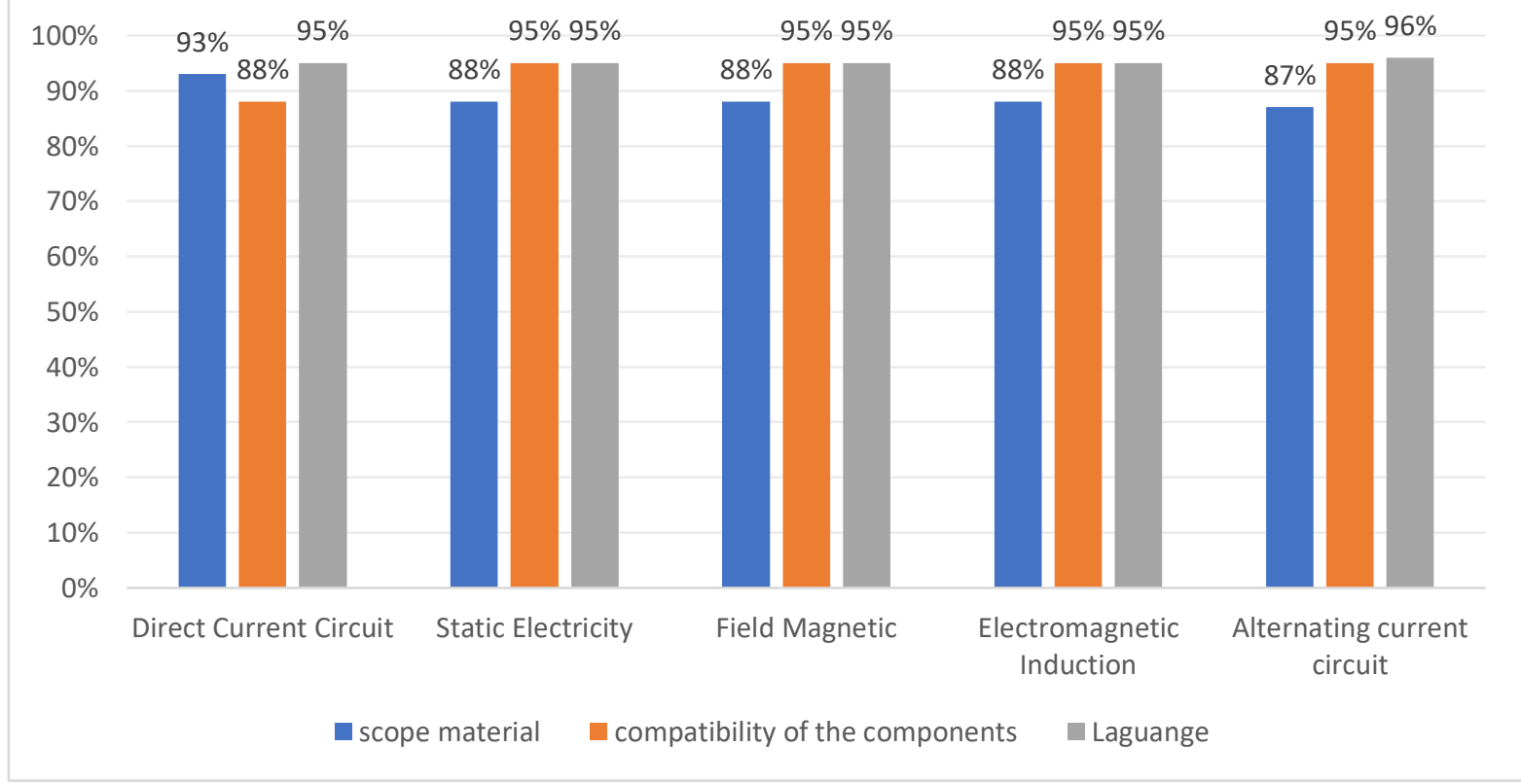

FIGURE 18. The results of the feasibility test by learning experts 
The results of the use of e-learning tools by users are 30 students in the form of multiple-choice pretest and post-test. The results of the N-Gain value of each chapter in e-learning can be seen in the following TABLE 3.

TABLE 3. N-Gain value of pre-test and post-test

\begin{tabular}{lccc}
\hline \multicolumn{1}{c}{ Topic } & Pre-Test & Post-Test & N-Gain \\
\hline Direct Current (DC) Circuit & 46 & 68 & 0.40 \\
Electricity Static & 27 & 56 & 0.39 \\
Magnetic Field & 35.6 & 61.2 & 0.37 \\
Electromagnetic Induction & 41 & 63.8 & 0.37 \\
Alternating Current (AC) Circuit & 42 & 62.6 & 0.35 \\
\hline
\end{tabular}

Based on TABLE 3, N-Gain can be obtained in the medium category in each material discussion. The N-Gain results on the topic of Direct Current (DC) Circuit are 0.40; on the topic of Electricity Static of 0.39; Magnetic Field topic of 0.37; Electromagnetic Induction topic of 0.37; and the topic Alternating Current (AC) Circuit of 0.35. So with e-learning with the 5E Learning Cycle strategy, students can improve their understanding of high school physics material.

\section{CONCLUSIONS}

Based on the results of formative evaluations by media experts, it was concluded that the e-learning tool used WordPress on high school physics material with a $5 \mathrm{E}$ learning cycle strategy rated as an electronic learning device with very good quality.

\section{REFERENCES}

Andi 2010, Membangun Website Tanpa Modal, Andi Offset, Yogyakarta.

Bakri, F, Fajriani, F, \& Muliyati, D 2017, 'Media E-Learning Berbasis CMS Joomla: Pelengkap Pembelajaran Fisika SMA', Jurnal Teknodik, vol. 21, no.2, pp. 99-110.

Bakri, F, Muliyati, D 2017, 'Pengembangan Perangkat E-Learning untuk Matakuliah Fisika Dasar II Menggunakan LMS Chamilo', Jurnal Wahana Pendidikan Fisika, vol. 2, no. 1, pp. 25-30.

Bakri, F, Sunaryo, Irawan, VF, \& Muliyati D 2018, 'E-Learning Model for Problem Based Learning on Heat and Thermodynamic Topics in High School', JPPPF (Jurnal Penelitian dan Pengembangan Pendidikan Fisika), vol. 4, no. 2, pp. 101-112, doi: doi.org/10.21009/1.04207.

Basuki, GD 2015, 'Pengembangan E-learning Berbasis Moodle Pembelajaran IPA Bagi Siswa Kelas V SD Negeri Kotagede 1', Jurnal Teknologi Pendidikan, vol. 1, no. 1, p. 2.

Darmawan, D 2014, E-learning dalam Konteks Pendidikan: Pengembangan E-Learning Materi dan Desain, PT Remaja Rosdakarya, Bandung, p.24.

Daru, AF 2013, 'Integrasi CMS dan LMS Untuk Membangun Web Berbasis E-Learning dengan Single Login', Jurnal Transformatika, vol. 11, no. 1, pp.23-31.

Daryanto 2014, Pendekatan Pembelajaran Saintifik Kurikulum 2013, Gava media, Yogyakarta.

Duran, LB, Duran, E 2004, 'The 5E Instructional Model: A Learning Cycle Approach for InquiryBased Science Teaching', Science Education Review, pp 49-58.

Ghaliyah, S, Bakri, F, \& Siswoyo 2015, 'Pengembangan Modul Elektronik Berbasis Model Learning Cycle 7E Pada Pokok Bahasan Fluida Dinamik Untuk Siswa SMA Kelas XI', Prosiding Seminar Nasional Fisika, IV.

Irwandani 2014, 'Multirepresentasi sebagai Alternatif Pembelajaran dalam Fisika', Jurnal Ilmiah Pendidikan Fisika Al-Biruni, vol. 3, no. 1, pp. 1-10.

Mahardika, I, Abdullah, Prihandono, T 2013, 'Penerapan Model Pembelajaran Interaktif Berbasis Konsep Untuk Meningkatkan Kemampuan Representasi Verbal, Matematik, dan Gambar Fisika 
Siswa Kelas VIII-A MTs N 1 Jember Tahun Pelajaran 2012/2013', Jurnal Pendidikan Fiska, vol. 2, pp. 272-277.

Meredith, DG, Walter, RB, \& Joyce, PG 2003, Educational Research: An Introduction (7th Edition), p.570.

Messenlehner, B, Coleman, J 2014, Building Web Apps With Wordpress, O'Reilly Media Inc, America.

Ninoriya, S, Chawan, PM, \& Meshram, BB 2008, 'CMS, LMS, and LCMS for E-Learning', IJCSI International Journal of Computer Science Issues, pp. 6444-647.

Sudibjo, A , Wasis 2013, 'Penggunaan Media Pembelajaran Fisika Dengan E-learning Berbasis Edmodo Blog Education Pada Materi Alat Optik Untuk Meningkatkan Respon Motivasi Dan Hasil Belajar Siswa Di SMP Negeri 4 Surabaya', Jurnal Inovasi Pendidikan Fisika, vol. 2, no. 3, p.188.

Suyoso, Nurohman, S 2014, 'Pengembangan Modul Elektronik Berbasis Web Sebagai Media Pembelajaran Fisika', Jurnal Kependidikan, vol. 44, no. 1, pp. 73-74.

Yulita, AR, Ambarwulan, D, \& Bakri, F 2018, 'Pengembangan E-Learning Menggunakan Chamilo Untuk Membantu Proses Pembelajaran Fisika SMA Kelas X Semester II', Gravity, vol. 4, no. 2, pp. $15-25$. 